\title{
Butterflies Extracts Show Antibacterial Activity
}

\author{
Reuven Rasooly ${ }^{\text {* }}$, Miriam Rothschild²\#, Yael Gov³, Paul Wolferstan4, Robert Nash4, \\ Paula Do1, Naomi Balaban ${ }^{1 *}$
}

\author{
${ }^{1}$ Foodborne Toxin Detection \& Prevention Research Unit, United States Department of Agriculture, Agricultural Research \\ Service, Western Regional Research Center, Albany, CA, USA \\ ${ }^{2}$ Ashton Wold, Peterborough, UK \\ ${ }^{3}$ Department of Human Microbiology, Sackler School of Medicine, Tel Aviv University, Tel Aviv, Israel \\ ${ }^{4}$ Aberystwyth University-IBERS, Aberystwyth, UK \\ Email: ^reuven.rasooly@ars.usda.gov, ^nbalaban@staphoff.com
}

How to cite this paper: Rasooly, R., Rothschild, M., Gov, Y., Wolferstan, P., Nash, R., Do, P. and Balaban, N. (2017) Butterflies Extracts Show Antibacterial Activity. Advances in Microbiology, 7, 467-479. https://doi.org/10.4236/aim.2017.76036

Received: April 18, 2017

Accepted: June 17, 2017

Published: June 20, 2017

Copyright $\odot 2017$ by authors and Scientific Research Publishing Inc. This work is licensed under the Creative Commons Attribution International License (CC BY 4.0).

http://creativecommons.org/licenses/by/4.0/

\begin{abstract}
Extracts of several British butterfly species were tested and shown to possess powerful bactericidal activity against gram-positive bacteria (tested on Staphylococcus aureus and Bacillus anthracis). The active compounds in the grass-feeding species were identified as hydroxylated pyrrolizidine alkaloids (PAs) related to loline with nitrogen at $\mathrm{C}-1$. Lolines are known insecticidal and insect-deterrent compounds that are produced in grasses infected by endophytic fungal symbionts. Lolines also increase resistance of endophyte-infected grasses to insect herbivores. The butterfly-isolated pyrrolizidine alkaloids appear to be novel and non-toxic to human cells such as HaCat human skin keratinocytes and Hep-2 human epithelial cells. The discovery of novel agents from butterflies could lead to the development of new antimicrobials.
\end{abstract}

\section{Keywords}

Pyrrolizidine Alkaloids, British Butterflies, Staphylococcus aureus, Antimicrobial

\section{Introduction}

Staphylococcus aureus are a Gram-positive aerobic bacteria that are usually nonpathogenic and are part of the normal skin flora. But once they produce toxins, they can cause major clinical infections and foodborne illnesses. These bacterium developed resistance to multiple antibiotics, and antibiotic resistance is on the rise globally. $S$. aureus cause diseases primarily by production of virulence factors such as enterotoxins and account for approximately 90,000 deaths a year in the US, resulting in high economic costs on patients and hospitals. Because 
this resistance causes a serious public health problem, there is a great need for development of novel approaches to combat $S$. aureus infections [1] [2].

Bacillus anthracis are gram-positive, spore-forming bacterium that belongs to the $B$. cereus group, which includes $B$. cereus, B. thuringiensis, B. mycoides, and $B$. weihenstephanensis [3]. It is a bioweapon because of its tough, environmentally resistant endospore and its ability to cause lethal inhalational anthrax. It causes disease through the secretion of toxins, such as lethal toxin and edema toxin, and a capsule encoded by the genes on two plasmids [4] [5].

In our previous work, we showed that green tea extract and phytochemicals like epigallocatechin gallate (EGCG) that are found in green tea, have high bactericidal activity against Gram-positive bacteria [6]. In Gram-negative bacteria such as Escherichia coli, EGCG also was shown to damage bacterial membranes and degrade exopolysaccharides, resulting in the destruction of biofilms [7].

After a butterfly caterpillar hatches from an egg, the caterpillar feed on fresh leaves of flowering plants that contain secondary metabolites, which include a wide variety of phytochemicals. Ingestion of these phytochemicals can provide natural protection to the insect. In addition, the butterfly contains antimicrobial agents that are produced within the butterfly and are part of its own immunity [8]. In this study, we tested the effect of extracts of butterfly species on the Gram-positive bacteria $S$. aureus and B. anthracis and the Gram-negative bacteria Pseudomonas aeruginosa and Proteus mirabilis.

\section{Materials and Methods}

\subsection{Sources of Butterflies and Grasses}

The study focused on grass-feeding species of butterfly but also included nettle (Urtica dioica) and milkweed-feeding Monarch butterfly. The majority of Lepidoptera and recently hatched larvae used were collected in the UK, in the woodland and surrounding meadows of Ashton Wold. Various grasses, suitable as food plants for the grass-feeding butterflies, were placed in sterilized loam in wooden trays and monitored for endophytic fungi. Each tray was then covered with white muslin and watered daily. First instars caterpillars were placed on the grasses, after which their development and habits were studied and compared. These trays were situated and supervised in a greenhouse, in intermittent sunshine, at Ashton Wold with an average temperature of $600^{\circ} \mathrm{F}$. Larval food plants for different butterflies is shown in Table 1 .

\subsection{Bacterial Strains and Growth Conditions}

S. aureus (strain ATCC 6538), S. aureus strain Smith diffuse [1], B. anthracis strain Sterne, a non-pathogenic vaccine strain [5], E. coli (USDA strain no. 16591), P. aeruginosa (strain ATCC 15442), and Proteus mirabilis (ATCC 29906) were grown in Luria-Bertani (LB) broth.

\subsection{Antibacterial Activity Assay}

S. aureus, B. anthracis, $P$. aeruginosa or $P$. mirabilis (1000 colony forming units 
Table 1. Larval food plants for different butterflies.

\begin{tabular}{cc}
\hline Butterfly & Larval food plants \\
\hline Peacock & Nettle (Urtica dioica) \\
Red Admiral & Thistle \\
Silver-washed Fritillary & Violets \\
Large Tortoiseshell & Young leaf tips of trees most commonly Elm \\
& (Ulmus) spp and sometimes Willows (Salix) \\
spp and Polar (Populus spp.)
\end{tabular}

(CFU)) were freshly prepared in $1 \mathrm{ml} \mathrm{LB}$ broth. Three $\mu \mathrm{l}$ of total extract or $5 \mu \mathrm{l}$ of each HPLC-eluted fraction were added to 97 or $95 \mu \mathrm{l}$ of bacteria respectively in sterile 96 well plates. Bacteria were grown for 24 hours at $37^{\circ} \mathrm{C}$ and density determined at OD $650 \mathrm{~nm}$. A sample was then also streaked on LB agar plates to confirm OD results. Control buffer was $3 \mu$ methanol (to a final 3\%) or HPLC carrier buffer (0.1 $\left.\mathrm{M} \mathrm{NH}_{4} \mathrm{OH}\right)$. Minimal Bactericidal Concentration (MBC) of butterfly extracts was performed by adding $5 \mu \mathrm{l}$ of material in question diluted in water or methanol to 1000 bacteria in culture media and growth continued overnight at $37^{\circ} \mathrm{C}$. Optical density was determined at $650 \mathrm{~nm}$ and a $3 \mu \mathrm{l}$ sample was grown on LB agar plates and CFU counted. Of note is that no bacterial growth was observed below A650 $=0.15$.

To test for the effect of loline and loline derivatives on bacterial growth, S. aureus and E. coli were grown as described above with or without $250 \mu \mathrm{g} / \mathrm{ml}$ of Loline, N-Acetylnorloline, N-Acetyl-5,6-dehydrololine, or N-Demethylloine (ChemFaces, Wuhan, Hubei, China). 0.5\% DMSO was used as a negative control.

\subsection{Treatment with Proteinase $\mathrm{K}$}

Total butterfly extracts $(3 \mu \mathrm{l})$ were incubated for $30 \mathrm{~min}$ at $37^{\circ} \mathrm{C}$ with $10 \mu \mathrm{g}$ Proteinase $\mathrm{K}$ in $100 \mu \mathrm{l}$ of water, or with water only as a control. Sample was then incubated at $65^{\circ} \mathrm{C}$ for $10 \mathrm{~min}$ to inactivate Proteinase K. Treated samples were evaporated, resuspended in $3 \mu \mathrm{l}$ methanol and tested for antibacterial activity as described above. To ensure that the Proteinase $\mathrm{K}$ was active, the same amount of enzyme $(10 \mu \mathrm{g})$ was added to $100 \mu \mathrm{g}$ BSA for $30 \mathrm{~min}$ at $37^{\circ} \mathrm{C}$, sample applied to SDS PAGE and gel stained by coomassie. The fact that BSA was degraded indicated that indeed the enzyme was active.

\subsection{Electrospray Ionization Mass Spectrometry}

Butterfly sample alkaloids were analyzed by GC-MS and by reaction with the classic alkaloid reagent Dragendorff's [9] both before and after a clean-up of 
aqueous ethanol extracts on IR-120 (H+ form cation exchange resin). While lolines react with Dragendorff's reagent, the active compounds did not. Analysis of butterfly extracts and loline was carried out by GC-MS using a Perkin Elmer Autosystem XL gas chromatograph with a high polarity fused-silica column (Varian "FactorFour" VF- $5 \mathrm{~ms}$ column, $25 \mathrm{~m} \times 0.25 \mathrm{~mm}$ i.d., $0.25 \mu \mathrm{m}$ phase thickness). The carrier gas (helium) flow rate was $1 \mathrm{ml} \cdot \mathrm{min}^{-1}$. Underivatised samples were run in $90 \%$ ethanol on a temperature program running from $50^{\circ} \mathrm{C}$ (held for 3 minutes) to $300^{\circ} \mathrm{C}$ over 30 minutes. Loline had a retention time of 12 minutes. Electron impact mass spectrometry of the column eluant was carried out using a Perkin Elmer TurboMass Gold mass spectrometer, with a quadrupole ion filter system, which was run at $250^{\circ} \mathrm{C}$ constantly during analysis. The detector mass range was set to 45 to $350 \mathrm{amu}$. The temperature of the transfer line (GC to MS) was held at $250^{\circ} \mathrm{C}$. Samples were injected onto the column via a split vent (split ratio 50:1) through a fused silica narrow bore injection liner packed with deactivated quartz wool; the injection port temperature was maintained at $200^{\circ} \mathrm{C}$. The injection volume was $1 \mu \mathrm{l}$. System control, data collection and mass spectral analysis was carried out using Perkin Elmer TurboMass software (TurboMass v.4.4).

\subsection{Effect on Human Cells}

HaCat human skin keratinocytes or Hep-2 human epithelial cells were applied to Costar 96-well cell culture polystyrene plates (Corning Inc., Corning NY, USA) $\left(10^{4}\right.$ cells/well $)$ and grown to reach confluency at $37^{\circ} \mathrm{C}$ in a $5 \% \mathrm{CO}_{2}$ humidified incubator in DMEM supplemented with 5\% FCS. Increasing amounts of butterfly extracts $(0-10 \mu \mathrm{l})$ were applied to the cells, cells incubated for $24 \mathrm{hrs}$, and cell viability determined colorimetrically by staining with 2,3-Bis(2-Methoxy-4-Nitro-5Sulfophenyl)-5-(Phenylamino) Carbonyl]-2H-Tetrazolium Hydroxide (XTT) [10].

Human melanoma and ovarian cancer cells (SCC1) were incubated with increasing amounts of butterfly extracts $(0-10 \mu \mathrm{l})$. Cells were plated out into 96 well tissue culture plates at an appropriate concentration and left overnight at $37^{\circ} \mathrm{C}, 5 \% \mathrm{CO}_{2}$ and $100 \%$ humidity. The medium was replaced with $0.5 \mathrm{mg} / \mathrm{ml}$ of the Ringlet samples in complete medium and $10 \% \mathrm{v} / \mathrm{v}$ AlamarBlue. Controls included medium only and $100 \%$ distilled water. After 24 hours the medium was transferred into a 96 well plate and OD have been read at $560 \mathrm{~nm}$ and $600 \mathrm{~nm}$. In the meantime, the cells were replenished with complete medium, without any drug, but with $10 \% \mathrm{v} / \mathrm{v}$ AlamarBlue. After 24 hours the OD was read again at 560 $\mathrm{nm}$ and $600 \mathrm{~nm}$.

\section{Results}

\subsection{Antibacterial Activity of Butterfly Extracts}

Multiple species of butterflies (Table 2) were tested for the presence of defensive antibacterial chemicals. Initially, butterflies (Ringlet and Meadow Brown) were extracted by water or methanol and each extract tested for antibacterial activity against $S$. aureus. Because only the methanol-extracted material was active, further extractions from all other butterflies were carried out in methanol only. As 
Table 2. Antibacterial activity found in various butterfly extracts against Gram-positive and Gram-negative bacteria. (+) growth (i.e. no antibacterial activity), (-) no growth (i.e. antibacterial activity).

\begin{tabular}{|c|c|c|c|c|}
\hline & $\begin{array}{c}\text { Growth of } \\
\text { Bacillus } \\
\text { anthracis }\end{array}$ & $\begin{array}{c}\text { Growth of } \\
\text { Staphylococcus } \\
\text { aureus }\end{array}$ & $\begin{array}{l}\text { Growth of } \\
\text { Proteus } \\
\text { mirabilis }\end{array}$ & $\begin{array}{c}\text { Growth of } \\
\text { Pseudomonas } \\
\text { aeruginosa }\end{array}$ \\
\hline Meadow Brown & - & + & + & + \\
\hline Ringlet & - & + & + & + \\
\hline Peacock & - & - & + & + \\
\hline Monarch & - & - & + & + \\
\hline Skipper & - & + & + & + \\
\hline $\begin{array}{l}\text { Gatekeeper } \\
\text { Female }\end{array}$ & - & - & + & + \\
\hline $\begin{array}{l}\text { Gatekeeper } \\
\text { Male }\end{array}$ & - & - & + & + \\
\hline $\begin{array}{c}\text { Marbled } \\
\text { White female }\end{array}$ & - & - & + & + \\
\hline Marbled White male & - & - & + & + \\
\hline $\begin{array}{l}\text { Large Tortoiseshell } \\
\text { female }\end{array}$ & - & - & + & + \\
\hline Red Admiral male & - & - & + & + \\
\hline Brimstone male & - & - & + & + \\
\hline $\begin{array}{l}\text { Silver washed } \\
\text { Fritillary female }\end{array}$ & - & - & + & + \\
\hline $\begin{array}{l}\text { Silver washed } \\
\text { Fritillary male }\end{array}$ & - & - & + & + \\
\hline Orange Tip male & - & - & + & + \\
\hline $\begin{array}{l}\text { Control 3\% } \\
\text { methanol }\end{array}$ & + & + & + & + \\
\hline
\end{tabular}

shown in Table 2, all extracts were active against gram-positive bacteria $B$. anthracis and most also against $S$. aureus.

None of the extracts were active against gram-negative bacteria $P$. aeruginosa and $P$. mirabilis. Antibacterial activity was retained after treatment of extracts with Proteinase K, suggesting that active components are not polypeptides.

MIC and MBC of each butterfly extract were tested and shown in Figure 1, and compared to those of conventional antibiotics. The MIC for $S$. aureus and $B$. anthracis e.g. of Red Admiral and Marbled White was 1:100, and Gatekeeper and Orange Tip was 1:10. The MBC was ten times higher than the MIC. MIC and $\mathrm{MBC}$ of ampicillin and ciprofloxacin were $0.1 \mu \mathrm{g} / \mathrm{ml}$ and $1.0 \mu \mathrm{g} / \mathrm{ml}$ respectively for these bacterial species, which is compatible with published data [11].

\subsection{Toxicity Testing}

To test if extracts are toxic to eukaryotic cells, HaCat human skin keratinocytes or Hep-2 human epithelial cells were incubated with increasing amounts of each 


\section{B. anthracis}

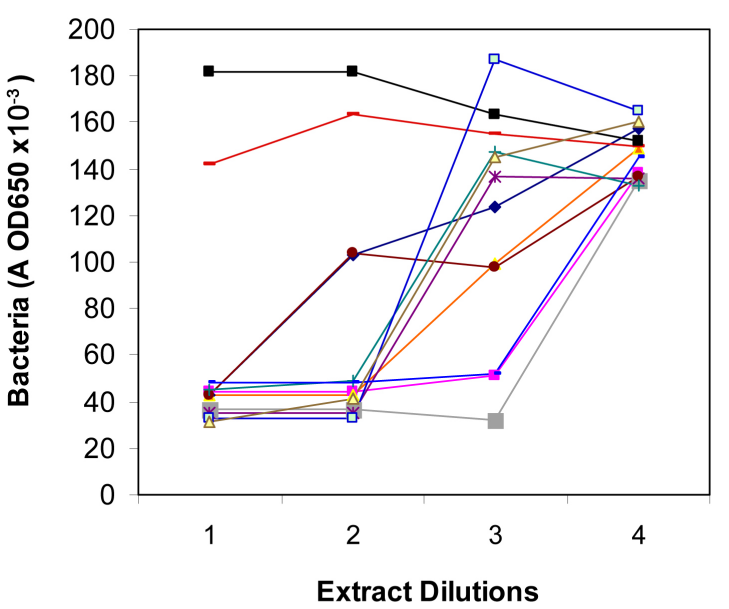

$\rightarrow-$ Gate Keeper F

- Marbled White M

- - - British Silver F

- Red Admiral M

* Tortoise Seashell F

- Brimstone M

- Orange Tip M

- Meadow brown

- methanol

- media

$\rightarrow-$ Cipro

$\rightarrow$ Amp

\section{S. aureus}

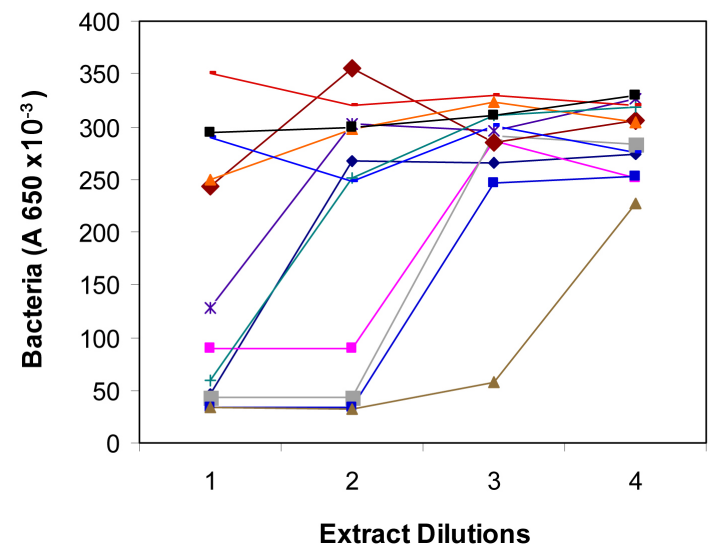

$\rightarrow$ Gate Keeper F

- Marbled White M

- Red Admiral M

$-*-$ Tortoise Seashell F

- Brimstone M

^-British Silver F

_- Orange Tip M

- Meadow brown

- methanol

$\rightarrow$ media

$\rightarrow$ - Cipro

$\simeq$ Amp

Figure 1. MIC test of butterfly extracts on growth of $S$. aureus and B. anthracis. Final dilutions of extracts: $1=1: 10,2=1: 100,3=1: 1000,4=1: 10,000$. Antibiotics final con-centration: Ciprofloxacin (Cipro, $\mu \mathrm{g} / \mathrm{ml}$ ) $1=1,2=0.1,3=0.01,4=0.001$. Ampicillin (Amp, $\mu \mathrm{g} / \mathrm{ml}$ ) $1=10,2=1,3=0.1,4=0.01$. Of note that Brimstone showed higher OD while almost no bacterial growth due to a certain opaqueness of the extract itself.

of the butterfly extracts, and 24 hrs later cell viability was tested colorimetrically using XTT [10]. Results (not shown) indicate that extracts had no visible signs of toxicity to the cells. Cytotoxicity was also tested on human melanoma and ovarian carcinoma cells by AlamarBlue, with no observable effect of any of the butterfly extracts.

\subsection{Purification of Active Compounds}

Crude methanol extracts were fractionated on a reverse phase HPLC column and eluted fractions were tested for antibacterial activity. As shown in Figure 2, most distinct active fraction of all extracts was the one eluted between 33\% - 35\% acetonitrile. Some additional active fractions were eluted around 46\% - 49\% acetonitrile but those were less distinctive and their activity was lost when refractionated using the same conditions. 


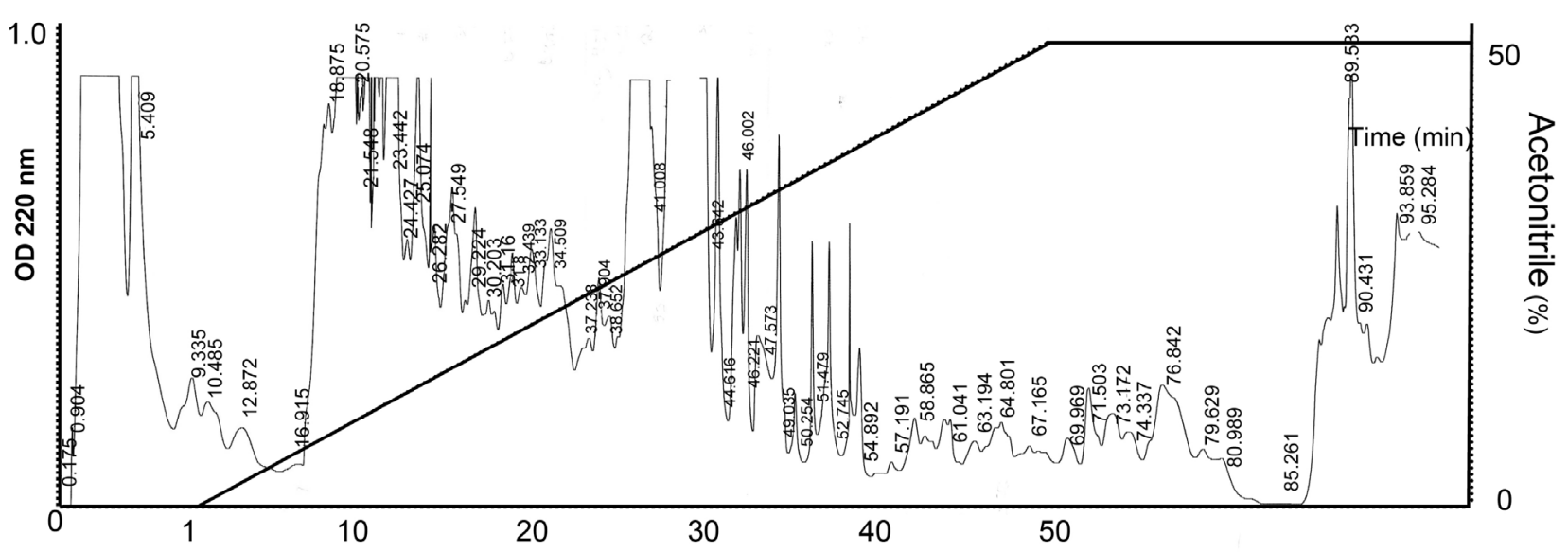

Fraction number

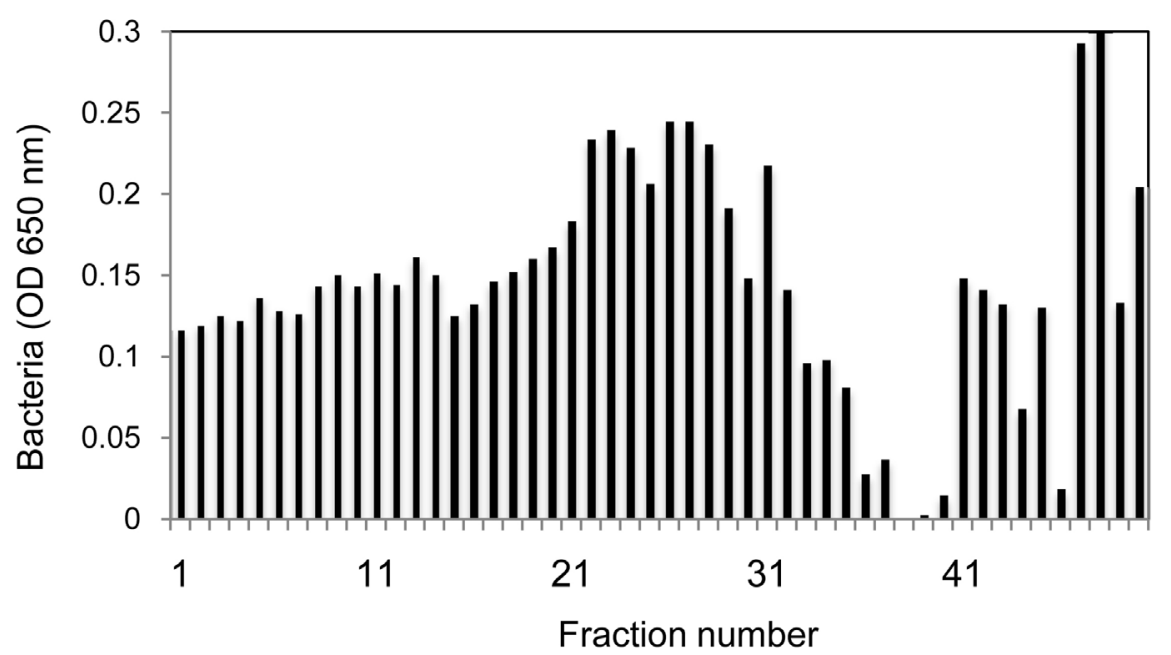

Figure 2. Sample HPLC purification and antibacterial activity profile of Meadow Brown extract. Top, HPLC profile determined at OD $220 \mathrm{~nm}$. Bottom, antibacterial as-says of eluted fractions (bacterial growth determined at OD $650 \mathrm{~nm}$ ).

\subsection{HPLC Fractionation and GC-MS Analysis}

The biologically active fractions from the HPLC separation of the butterfly extracts were analyzed by GC-MS and by reaction with the classic alkaloid detection reagent (Dragendorff), both before and after treatment of $70 \%$ or $90 \%$ aqueous ethanol extracts on cation exchange resin (Figure 3). Identification of loline-related compounds in the active fractions was based on comparison of the gas chromatographic retention times and characteristic mass spectra of the alkaloids found [12] [13]. The mass spectrum of loline gave a major ion at $82 \mathrm{amu}$ (Figure 4(a)) and this ion is distinctive of loline derivatives (Figure 4(b) and Figure 4(c)). The compounds described here (Figure 4(d)), which are presumed to have the furan ring open, give distinctive mass spectra with major ions at either 84 or 86 (Figure 3 and Figure 4(d)). The difference in the ions being either 84 or 86 is caused by opening of the furan ring to give an oxygen either on C-2 (giving major fragment $84 \mathrm{amu}$ ) or C-7 (major fragment $86 \mathrm{amu}$ ). Variations on these basic structures can occur such as unsaturation after opening of the furan ring and alkyl groups on the nitrogen at $\mathrm{C}-1$. The active fractions were not reactive 

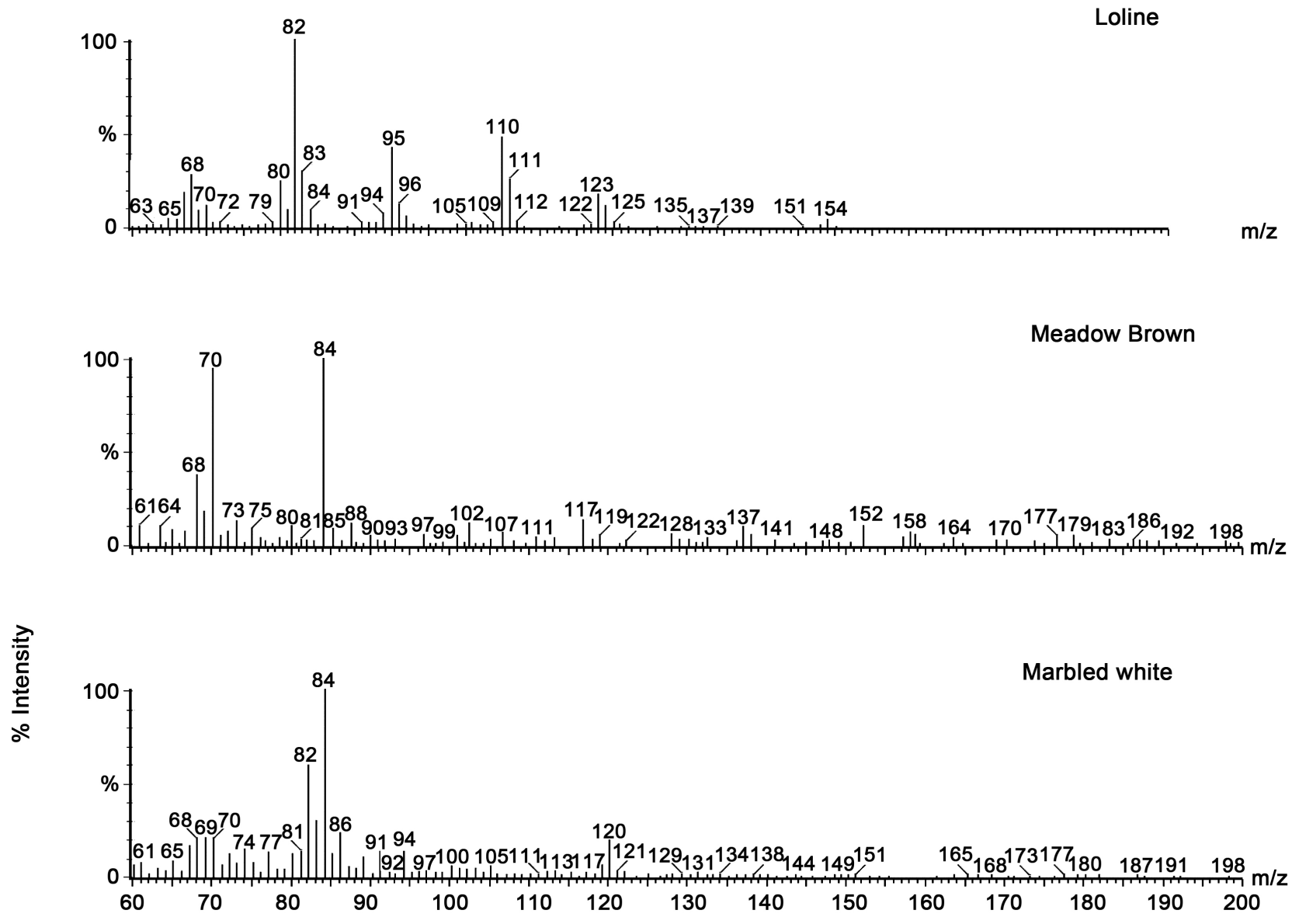

Meadow Brown 90\% ethanol

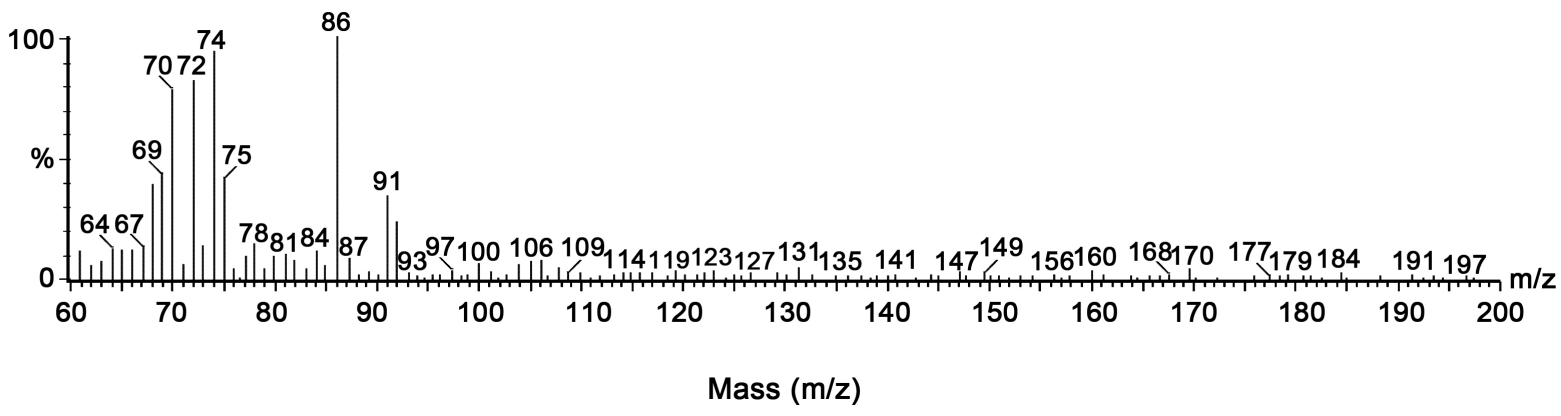

Figure 3. The mass spectrum of loline and characteristic mass spectra of loline-related compounds in butterflies from the fractions that have the antimicrobial activity.

with Dragendorffs reagent.

\subsection{The Effect of Loline and Its Derivatives on Bacterial Growth}

The effect of loline or its derivatives on gram positive ( $S$. aureus) and gram negative (E. coli) bacteria was tested by growing the cells in the presence of 250 $\mu \mathrm{g} / \mathrm{ml}$ Loline, N-Acetylorloline, N-Acetyl-5,6-dehydrololine, or N-Demethylloine. As shown in Figure 5, these molecules had no effect on bacterial growth, 


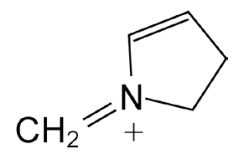

(a)

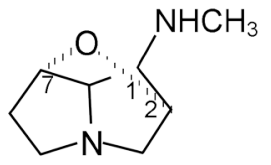

(b)<smiles>O=Cc1ccn2c1CCC2</smiles>

(c)<smiles>CNC1C(O)CN2CCCC12</smiles>

(d)

Figure 4. Chemical structures of (a) Loline major MS fragment at 82 amu; (b) Loline; (c) Danaidal; (d) The compounds described here which are presumed to have the furan ring open.

supporting our hypothesis that it is not loline itself that is causing the antibacterial effect observed in butterfly extracts.

\section{Discussion}

Our study describes the isolation of pyrrolizidine alkaloids (PAs) in grass-feeding British butterflies that are active against gram-positive bacteria ( $S$. aureus and $B$. anthracis) but not against gram-negative bacteria ( $P$. aeruginosa and $P$. mirabilis). Several of the grass food plants are known to contain modified or precursors of PAs [14]. Loline alkaloids are also produced by mutualistic fungi symbiotic with grasses, and may be the source of the PAs we have found in the adult butterflies [15] [16] [17] [18]. The association of the symbiotic fungal endophytes with the food plants of these species is widespread, but erratic. As shown in Table 1, the larvae of these butterflies feed on a variety of grasses, which include Perennial Rye-grass (Lolium perenne) and various Fescues, especially in the UK Festuca rubra and Festuca ovata. The Ringlet favours grass species such as Wood Millet (Milium effusum), Wood False-brome (Brachypodium sylvaticum), Cock's-foot (Dactylis glomerata), and sedges for example Carex spp., while the Meadow Brown prefers Bents (Agrotis spp.) and Poa spp. and in many cases, like the food plant of the Marbled White [16], the distribution of the eggs is also erratic. These grasses may possess the precursors of PAs, fungal parasites, symbionts, and various ecto- and [19] [20], but as far as is known, grasses do not themselves produce PAs. The occurrence of the endophytes can 

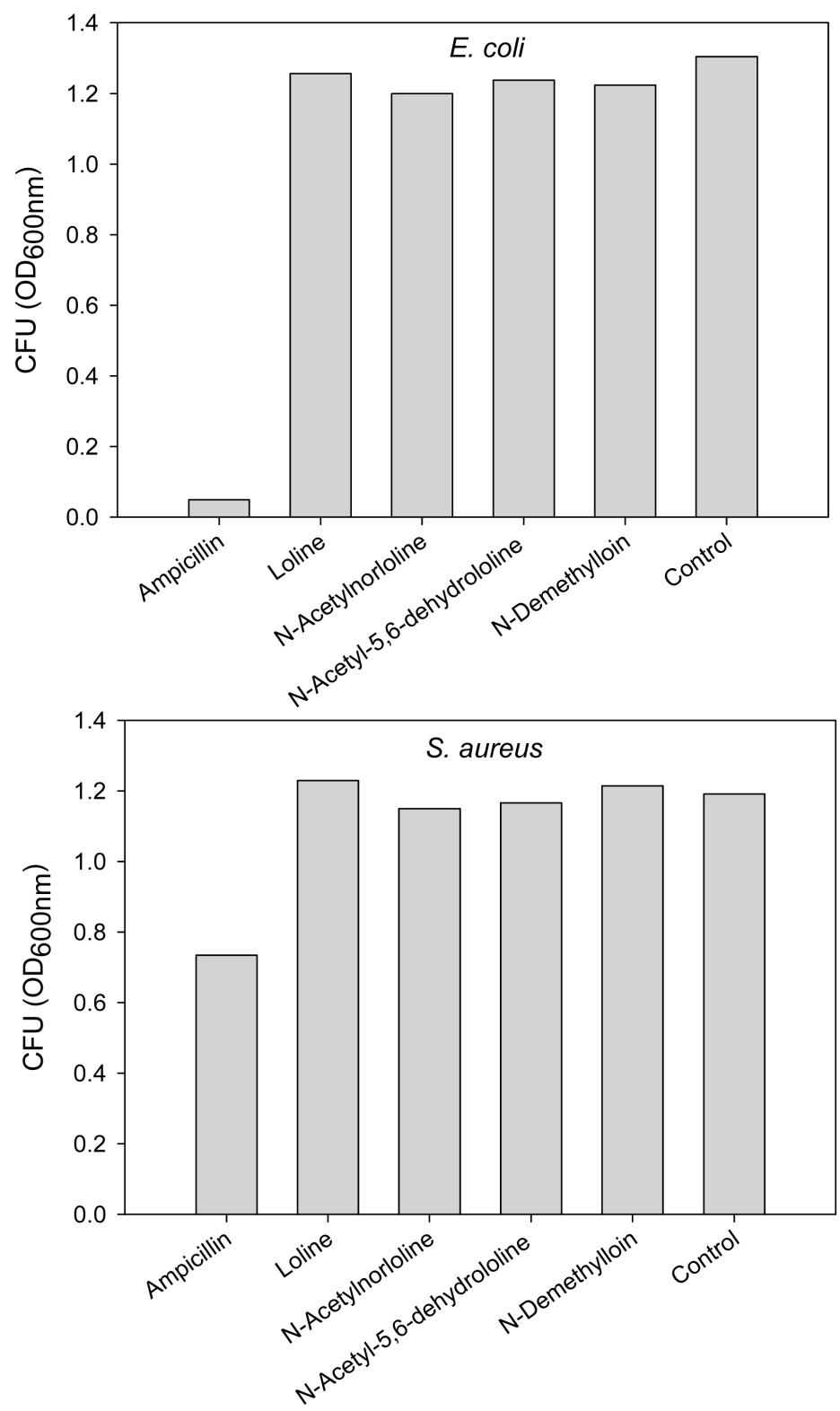

Figure 5. The effect of loline and its derivatives on bacterial growth.

vary from $100 \%$ to nil in the grass growing in meadows, on airfields, along road verges, in the roughs of golf courses and woodland rides etc. Richardson [20], has recorded over 200 grass endophytes). We therefore suggest that the saturated PAs that we found in the larva, pupa and adult of the semi-colonial Marbled Whites, were originally obtained from the symbiotic endophytes associating with their food [15] [16] [20]. In culturing the Mabled White larvae it was noted that they sought grass containing endophyte in preference to grass without the fungus.

The PA Danaidal (1-formyl-6,7-dihydro-5H-pyrrolizine) had been reported as a pheromone [21] in some exotic butterflies [22]. More recently classic PAs from plants such as Ragwort (Senecio jacobaea) have been reported to be anti-bacterial, however, they are too toxic to be suitable as oral drugs [23] [24] [25]. 
Interestingly, unsaturated PAs are one of the most widely spread plant poisons [26] [27] [28] and are probably the most poisonous single group of alkaloids. They are hepatotoxins converted to toxic pyrroles in vivo and cause death and liver damage [29]. In the United States, the less toxic saturated alkaloids are frequently used for the protection of agricultural crops, including lawns in gardens, from the persistent attack by a wide range of herbivorous insects. The PAs we discovered do not appear to be toxic to mammalian cells and are not the pro-toxic 1,2-dehydropyrrolizidines that form toxic pyrroles and so could potentially be used to derive a new family of drugs for microorganisms resistant to current antibiotics.

Loline, which is the best known of this group of PAs, or a few of its known derivatives tested, are not themselves antibacterial, but could form the basis for the development of a new class of antibiotics. Full synthesis of a range of alkaloids related to loline is underway to confirm the structure and function of the loline-related compounds present in the active fractions from the insect extracts.

The presence of a potential antibiotic in various British butterflies indicates an important area for research in both insects and the chemicals associated with their food plants. The results of our investigations emphasize the importance of the conservation of nature, not only its aesthetic value and interest, but also as an unquestionable benefit to humanity.

\section{Acknowledgements}

We would like to note that initially this research was undertaken at Ashton by late Miriam Rothschild together with late Kennedy McWhirter, when they both thought that these butterflies probably contain antibiotics. We thank Dr Robin Aplin and Kate Garton for their invaluable help in the preparation of this manuscript. We thank Prof Sir Aaron Klug, Prof Sir John Walker, and Dr Graham Lewis for their advice and assistance with chemical analysis; Prof Paul Brakefield, Dr Helene de Voss for general assistance; Dr Clive Farrell, Dr Robert Gooden, Dr Michael Mullis, Dr Martin White, Dr Nigel South, Dr Richard VaneWright, Dr Philip Ackery, Dr David Carter and British Museum (Natural History) for collection and supply of insect material; Prof Monique Simmonds, Paul Cooper, Berit Pederson, Dr Rupert Lee and Drs Sheila and Terry Wells for their assistance with the literature; the late Prof Franklyn Perring who assisted us in identifying the grasses, Peter Scott for collecting local material and for his care of the grasses; BBSRC for a grant to Paul Wolferstan.

\section{References}

[1] Balaban, N., Goldkorn, T., Nhan, R.T., Dang, L.B., Scott, S., Ridgley, R.M., Rasooly, A., Wright, S.C., Larrick, J.W., Rasooly, R. and Carlson, J.R. (1998) Autoinducer of Virulence as a Target for Vaccine and Therapy against Staphylococcus aureus. Science, 280, 438-440. https://doi.org/10.1126/science.280.5362.438

[2] Purrello, S.M., Garau, J., Giamarellos, E., Mazzei, T., Pea, F., Soriano, A. and Stefani, S. (2016) Methicillin-Resistant Staphylococcus aureus Infections: A Review of the Currently Available Treatment Options. Journal of Global Antimicrobial Resis- 
tance, 7, 178-186. https://doi.org/10.1016/j.jgar.2016.07.010

[3] Henderson, I., Yu, D. and Turnbull, P.C. (1995) Differentiation of Bacillus anthracis and Other "Bacillus cereus Group" Bacteria Using IS231-Derived Sequences. FEMS Microbiology Letters, 128, 113-118. https://doi.org/10.1111/j.1574-6968.1995.tb07509.x

[4] Koehler, T.M. (2002) Bacillus anthracis Genetics and Virulence Gene Regulation. Current Topics in Microbiology and Immunology, 271, 143-164. https://doi.org/10.1007/978-3-662-05767-4_7

[5] Kiran, M.D., Bala, S., Hirshberg, M. and Balaban, N. (2010) YhgC Protects Bacillus anthracis from Oxidative Stress. The International Journal of Artificial Organs, 33, 590-607.

[6] Rasooly, R., Hernlem, B., He, X. and Friedman, M. (2015) Plant Compounds Enhance the Assay Sensitivity for Detection of Active Bacillus cereus Toxin. Toxins, 7, 835-845. https://doi.org/10.3390/toxins7030835

[7] Matsunaga, T., Nakahara, A., Minnatul, K.M., Noiri, Y., Ebisu, S., Kato, A. and Azakami, H. (2010) The Inhibitory Effects of Catechins on Biofilm Formation by the Periodontopathogenic Bacterium, Eikenella Corrodens. Bioscience, Biotechnology, and Biochemistry, 74, 2445-2450. https://doi.org/10.1271/bbb.100499

[8] Woestmann, L., Kvist, J. and Saastamoinen, M. (2017) Fight or Flight?_Flight Increases Immunegene Expression but Does Not Help to Fight an Infection. Journal of Evolutionary Biology, 30, 501-511. https://doi.org/10.1111/jeb.13007

[9] Farnsworth, N.R. (1966) Biological and Phytochemical Screening of Plants. Journal of Pharmaceutical Sciences, 55, 225-276. https://doi.org/10.1002/jps.2600550302

[10] Hawser, S.P., Norris, H., Jessup, C.J. and Ghannoum, M.A. (1998) Comparison of a 2,3-bis(2-methoxy-4-nitro-5-sulfophenyl)-5-[(phenylamino)carbonyl]-2H-tetrazoli um hydroxide (XTT) Colorimetric Method with the Standardized National Committee for Clinical Laboratory Standards Method of Testing Clinical Yeast Isolates for Susceptibility to Antifungal Agents. Journal of Clinical Microbiology, 36, 1450 1452 .

[11] National Committee for Clinical Laboratory Standards (2001) Performance Standards for Antimicrobial Susceptibility Testing (Suppl. 11) M100-S11, USA, Wayne.

[12] Rothschild, M. and Edgar, J.A. (1978) Pyrrolizidine Alkaloids from Senecio vulgaris Sequestered and Stored by Danaus plexippus. Journal of Zoology, 186, 347-349. https://doi.org/10.1111/j.1469-7998.1978.tb03923.x

[13] Schoch, T.K., Gardner, D.R. and Stegelmeier, B.L. (2000) GC/MS/MS Detection of Pyrrolic Metabolites in Animals Poisoned with the Pyrrolizidine Alkaloid Riddelliine. Journal of Natural Toxins, 9, 197-206.

[14] Hegnauer, R. (1988) Biochemistry, Distribution and Taxonomomic Relevance of Higher Plant Alkaloids. Phytochemistry, 27, 2423. https://doi.org/10.1016/0031-9422(88)87006-7

[15] Rothschild, M. and Nash, R. (1993) The Chemical Defences of the Imago of Three Nymphalid Butterflies. Antenna, 17, 74-75.

[16] Rothschild, M. (2001) The Marbled White (Melanargia galathea) a Toxic Butterfly. Antenna, 25, 176-177.

[17] Spiering, M.J., Moon, C.D., Wilkinson, H.H. and Schardl, C.L. (2005) Gene Clusters for Insecticidal Loline Alkaloids in the Grass-Endophytic Fungus Neotyphodium uncinatum. Genetics, 169, 1403-1414. https://doi.org/10.1534/genetics.104.035972

[18] Schardl, C.L., Grossman, R.B., Nagabhyru, P., Faulkner, J.R. and Mallik, U.P. (2007) Loline al-Kaloids: Currencies of Mutualism. Phytochemistry, 68, 980-996. 
https://doi.org/10.1016/j.phytochem.2007.01.010

[19] Bush, L.P., Fannin, F.F., Siegel, M.R., Dahlman, D.L. and Burton, H.R. (1993) Chemistry, Occurrence and Biological Effects of Saturated Pyrrolizidine Alkaloids Associated with Endophyte-Grass Interactions. Agriculture, Ecosystems and Environment, 44, 81-102. https://doi.org/10.1016/0167-8809(93)90040-V

[20] Richardson, M.D. (2000) Alkaloids of Endophyte-Infected Grasses: Defence Chemicals or Biological Anomalies? In: Bacon, C.W. and White, J.F., Eds., Microbial Endophytes, Marcel Dekker Inc., New York, 323-340.

[21] Boppré, M. (1986) Insects Pharmacophagously Utilizing Defensive Plant Chemicals (Pyrrolizidine Alkaloids). Naturewissenschaften, 73, 17-26. https://doi.org/10.1007/BF01168801

[22] Edgar, J.A., Culvenor, C.C. and Smith, L.W. (1971) Dihydropyrrolizine Derivitatives in the Hair-Pencil Secretion of Danaid Butterflies. Experientia, 27, 761. https://doi.org/10.1007/BF02136849

[23] Barsoum, F.F. and Nawar, N.N. (2003) Synthesis of Novel 1H-Pyrrollizine-5-Carboxamides and Their Antimicrobial Properties. Bollettino Chimico Farmaceutico, 142, 160-166.

[24] Jain, S.C. and Sharma, R. (1987) Antimicrobial Activity of Pyrrolizidine Alkaloids from Heliotropin ellipticum. Chemical and Pharmaceutical Bulletin, 35, 3487-3489. https://doi.org/10.1248/cpb.35.3487

[25] Singh, B., Sahu, P.M. and Singh, S. (2002) Antimicrobial Activity of Pyrrolizidine Alkaloids from Heliotropin subulatum. Fitoterapia, 73, 153-155. https://doi.org/10.1016/S0367-326X(02)00016-3

[26] Harborne, J.B. and Baxter, H. (1993) Pyrrolizidine Alkaloids. In: Taylor, F., Ed., Phytochemical Dictionary, Bristol, 255-266.

[27] Brown Jr., K.S. and Trigo, J.R. (1995) The Ecological Activity of Alkaloids. The Alkaloids, 47, 227-354.

[28] Aplin, R.T., Benn, M.H. and Rothschild, M. (1968) Poisonous Alkaloids in the Body Tissues of the Cinnabar Moth (Callimorpha jacobaeae L.). Nature, 219, 747-748. https://doi.org/10.1038/219747a0

[29] Schoenthal, R. and Magee, P.N. (1959) Further Observations on the Subacute and Chronic Liver Changes in Rats after a Single Dose of Various Pyrrolizidine (Senecio) Alkaloids. The Journal of Pathology and Bacteriology, 78, 471. https://doi.org/10.1002/path.1700780213 
Submit or recommend next manuscript to SCIRP and we will provide best service for you:

Accepting pre-submission inquiries through Email, Facebook, LinkedIn, Twitter, etc. A wide selection of journals (inclusive of 9 subjects, more than 200 journals)

Providing 24-hour high-quality service

User-friendly online submission system

Fair and swift peer-review system

Efficient typesetting and proofreading procedure

Display of the result of downloads and visits, as well as the number of cited articles Maximum dissemination of your research work

Submit your manuscript at: http://papersubmission.scirp.org/

Or contact aim@scirp.org 